ISSN 0103-8478

\title{
Temporary occlusion of the inferior lacrimal punctum and canaliculi of dogs with n-butyl-cyanoacrylate and 2-octyl-cyanoacrylate
}

\author{
Oclusão temporária do ponto e canalículo lacrimais inferiores de cães com n-butil-cianoacrilato e \\ 2-octil-cianoacrilato
}

\author{
Cristiane dos Santos Honsho ${ }^{\mathrm{I}^{*}}$ Karym Christine de Freitas Cardoso ${ }^{\mathrm{I}}$ Carolina Quarterone $^{\mathrm{II}}$ \\ Leandro Guimarães Franco ${ }^{\mathrm{III}}$ Adriana Torrecilhas Jorge Brunelli ${ }^{\mathrm{I}}$ \\ Fernanda Gosuen Gonçalves Dias ${ }^{\mathrm{IV}}$ Geórgia Modé Magalhães ${ }^{\mathrm{I}}$
}

\section{ABSTRACT}

The occlusion of the inferior lacrimal punctum limits tear drainage and thus keeps it over the ocular surface, prolongs lubrication and minimizes the need of ocular lubricants. The aim of this study was to evaluate the effectiveness of n-butyl-cyanoacrylate and 2-octyl-cyanoacrylate adhesives in the occlusion of the inferior lacrimal punctum and canaliculi of dogs and their clinical repercussions over 180 days. Eleven dogs, were divided into two groups: occlusion with $n$-butyl-cyanoacrylate $(G B, n=6)$ and with 2-octyl-cyanoacrylate $(G O, n=5)$. Tear production, blepharospasm, ocular discharge, epiphora and conjunctival hyperemia were analyzed before the procedure and on days (T) 3,7,15, 30, 45, 60, 90, 120, 150 and 180 after the procedure. Tear production of $G B$ was significantly higher at T90 $(P=0.0282)$ than its control. Variations between days showed that $T 7(P=0.0069)$ and $T 180 \quad(P=0.0207)$ varied significantly from $T 0$. In the GO group, when treatment was compared to control, T15 $(P<0.001)$ was significantly different from the rest. Variations between days showed that $T 15$ was significantly different than T0 ( $P=0.0044), T 3(P=0.0234), T 60(P=0.0207)$ and T90 ( $P=0.0482)$. No significant difference was observed between the treatment groups at any given time. It was concluded that both adhesives were effective in occluding lacrimal drainage for long periods and could thus be considered as therapeutic options in treating animals with lacrimal deficiency.

Key words: biomaterial, keratoconjunctivitis sicca, tear.

RESUMO

A oclusão do ponto lacrimal inferior limita a drenagem da lágrima, mantendo-a sobre a superficie ocular prolonga a lubrificação e minimiza a posologia de lubrificantes. Objetivou-se, com este estudo, avaliar a efetividade dos adesivos n-butil-cianoacrilato e 2-octil-cianocacrilato, na oclusão do ponto e canalículo lacrimais inferiores de cães e suas repercussões clínicas durante 180 dias. Para tanto, utilizaramse 11 cães distribuídos em dois grupos: oclusão com n-butilcianoacrilato $(G B, n=6)$ e com 2-octil-cianoacrilato $(G O ; n=5)$. A produção lacrimal foi avaliada previamente ao procedimento e, posteriormente, aos 3, 7, 15, 30, 45, 60, 90, 120, 150 e 180 dias, assim como blefarospasmo, secreção ocular, epifora e hiperemia conjuntival. A produção lacrimal de $G B$ diferiu significativamente de seu controle no momento T90 $(P=0,0282)$. Entre momentos, $T 7(p=0,0069)$ e T180 (P=0,0207), diferiram de T0. Em GO, comparando-se tratamento e controle, T15 $(P<0,001)$ diferiu-se estatisticamente dos demais. Ao se compararem os momentos, verificou-se que T15 diferiu significativamente de T0 $(P=0,0044)$, T3 $(P=0,0234), T 60(P=0,0207)$ e T $90(P=0,0482)$. Não foi observada diferença entre os tratamentos ao longo do tempo. Concluiu-se que ambos os adesivos foram efetivos para a oclusão da drenagem lacrimal por longo período, sendo uma opção factivel para animais com deficiência do filme lacrimal.

Palavras-chave: biomaterial, ceratoconjuntivite seca, lágrima

\section{INTRODUCTION}

The tear film is responsible for maintaining the uniformity of the optical surface by aiding the removal of particles, lubrication, nutrition and control of bacterial growth on the optical surface (GELATT, 2007; MAGGS et al., 2013). Tear film deficiency can predispose to dehydration of the cornea and conjunctiva, greater friction of the eyelids on the ocular surface, reduction of the oxygenation of the epithelium and sub-epithelial stroma, corneal and corneal-conjuctival inflammation with stromal

'Programa de Pós-graduação em Medicina Veterinária de Pequenos Animais, Universidade de Franca, (UNIFRAN), R. Dr. Armando Salles de Oliveira, 201. Pq. Universitário, 14404-600, Franca, SP, Brasil. E-mail: cristiane.honsho@unifran.edu.br.*Autor para correspondência. "Programa de Pós-graduação em Anestesiologia Veterinária, Universidade Estadual Paulista (UNESP), Botucatu, SP, Brasil.

IIIPrograma de Pós-graduação em Ciência Animal, Universidade Estadual de Santa Cruz (UESC), Ilhéus, BA, Brasil.

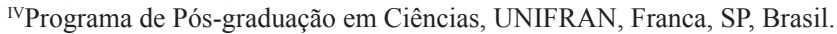


vascularization and pigmentation, secondary bacterial infection and corneal ulcer, amongst others (SANCHEZ et al., 2007; MAGGS et al., 2013).

The occlusion of the lacrimal punctum preserves naturally produced tears and prolongs its desired effects (GELATT, 2007; MAGGS et al., 2013). Thus, it can be used as an alternative treatment in cases non-responsive to pharmacological stimulation of tear production and ocular lubrication (PATEL \& GRIERSON, 1994; DIAMOND et al., 1995; YEN et al., 2001; LIU \& SADHAN, 2002; KAIDO et al., 2004). Temporary occlusion of the lacrimal punctum can be achieved through the use of adhesives, gelatin implants, collagen or silicone while permanent occlusion requires the use of techniques such as electrocautery (PATEL \& GRIERSON, 1994; OHBA et al., 2011), radiofrequency, laser or ligation of the lacrimal canaliculi (DIAMOND et al., 1995; MURUBE \& MURUBE, 1996; OHBA et al., 2011).

PATTEN (1976) and DIAMOND et al. (1995) reported good occlusion results when n-butylcyanoacrylate was used on the lacrimal punctum and nasolacrimal duct of humans, respectively; however, no information was provided on local tissue damage. Recently, CARDOSO et al. (2013) analyzed the clinical and histological effects of temporary occlusion of the punctum and nasolacrimal duct of rabbits with n-butyl-cyanoacrylate and 2-octyl-cyanoacrylate. These authors reported that both adhesives were easy to handle and apply and were efficient in occluding the punctum and nasolacrimal duct. Furthermore, both adhesives resulted in inflammatory and foreign body reaction that evolved into regeneration. Thus, based on the good results obtained in rabbits and the absence of reported complications, this study aimed to analyze, over a 6-month period, the long-term clinical repercussions and the efficacy of n-butylcyanoacrylate and 2-octyl-cyanoacrylate adhesives in the occlusion of the inferior lacrimal punctum and canaliculi of dogs.

\section{MATERIAL AND METHODS}

This study followed the guidelines of the Association for Research in Vision and Ophthalmology (ARVO, 2013) and complied with the rules and regulations of the Ethical Commission in the Use of Animals (CEUA).

Eleven healthy male and female mixed breed dogs, vaccinated and with an average weight of $16.3 \pm 5 \mathrm{~kg}$ were obtained from the Experimental Kennels of the of the University of Franca/SP-Brazil. Prior to treatment, animals were clinically evaluated and complete hemogram, urinalysis and liver and kidney function were analyzed. Animals presented with any ophtalmopathy were excluded from the study. All animals were positive for Jones test.

Animals were divided into two experimental groups, named after the adhesive being used in the occlusion of the inferior lacrimal punctum and canaliculi of the right eye: Group n-butylcyanoacrylate $^{\mathrm{a}}(\mathrm{GB}, \mathrm{n}=6)$ and Group 2-ocytilcyanoacrylate $^{\mathrm{b}}(\mathrm{GO}, \mathrm{n}=5)$. Contralateral eyes were used as control.

After fasting, animals received $0.05 \mathrm{mgkg}^{-1}$ acepromazinechlorhydrate $^{\mathrm{c}}$ associated with $2 \mathrm{mgkg}^{-1}$ meperidine ${ }^{\mathrm{d}}$ IM as pre-anesthetic medicine. Anesthetic induction was performed through the use of an intrave nous bolus of propofol ${ }^{\mathrm{e}}$ $\left(3.5 \mathrm{mgkg}^{-1}\right)$ and fentanyl ${ }^{\mathrm{f}}\left(1 \mu \mathrm{gkg}^{-1}\right)$. Throughout the surgical procedure animals received Ringer Lactate IV at $5 \mathrm{mlkg}^{-1} \mathrm{~h}^{-1}$ and were placed in left lateral recumbency.

Preoperative right eye antisepsis was carried out using topic 1:100 polyvinylpyrrolidone iodine (PVPI) in $0.9 \%$ sodium chloride and the eye surface dried with a sterile swab. For the occlusion of the inferior lacrimal canaliculi and punctum of the right eye, a $24 \mathrm{G}$ catheter attached to a $1 \mathrm{ml}$ syringe containing $0.3 \mathrm{ml}$ of the adhesive was used. The tip of the catheter was inserted into the lacrimal canaliculi, which was gently filled with the adhesive as the catheter was slowly removed. At the end of the procedure, the polymerized adhesive could be seen over the lacrimal punctum and any remaining adhesive on the ocular surface was removed with the aid of a sterile swab or Adson forceps. At the end of the surgical procedure, meloxicam at $0.2 \mathrm{mgkg}^{-1}$ was given IM and prescribed orally at $0.1 \mathrm{mgkg}^{-1}$ for three consecutive days.

The tear volume over the ocular surface was measured using Schirmer's Tear test ${ }^{\mathrm{g}}$ prior to occlusion (T0) and at Days 3 (T3), 7 (T7), 15 (T15), 30 (T30), 45 (T45), 60 (T60), 90 (T90), 120 (T120), 150 (T150) and 180 (T180) after occlusion. Concomitantly the presence of discomfort (blepharospasm), ocular discharge, epiphora and conjuctival hyperemia were analyzed using the following score chart: 0 (absence), 1 (mild), 2 (moderate), 3 (severe). All analysis was performed in the afternoon, at the same place and by the same observer.

On Days 70 and 180 Jones test was performed to evaluate the drainage, or lack of fluorescein. The bulbar conjunctiva was touched with the fluorescein strip ${ }^{i}$ and 2-3 drops of saline solution administered over the ocular surface. The 
presence (positive) or absence (negative) of the dye in the nostril was determined after 10 minutes of administration.

Results are presented as average and standard deviation. Statistical analysis was performed using the computer program JandelSigmaStat ${ }^{\text {h }}$ for Windows. The data obtained were subjected to Kolmogorov-Smirnov normality test. Data regarding the results obtained from the Schirmer's Tear Test were analyzed using ANOVA followed by StudentNewman-Keuls test for differences between the different time periods within each group. T-test was used to compare the differences between the two experimental groups.

For the results obtained for the conjuctival hyperemia, scleral congestion, epiphora, blepharospasm and ocular discharge, the Kruskal Wallis test was used to compare the different time periods within each group while the Mann Whitney test used for comparisons between groups. Significance was considered at $\mathrm{P} \leq 0.05$.

\section{RESULTS}

In the GB group, there was a significant increase in tear production of treated eyes at $\mathrm{T} 7$ $(\mathrm{P}=0.0069)$ and $\mathrm{T} 180(\mathrm{P}=0.0207)$ when compared to T0 (Figure 1A). A significant difference could also be observed at T90 $(\mathrm{P}=0.0282)$ between treated and non-treated eyes. In the GO group, there was significant increase in tear production of treated eyes at $\mathrm{T} 15$ when compared to $\mathrm{T} 0(\mathrm{P}=0.0044), \mathrm{T} 3$ $(\mathrm{P}=0.0234), \mathrm{T} 60(\mathrm{P}=0.0207)$ and $\mathrm{T} 90(\mathrm{P}=0.0482)$ (Figure 1B). A significant difference could also be observed at T15 $(\mathrm{P}<0.001)$ when treated and nontreated eyes were compared.

No significant difference was observed between the two treatment groups, however, GO showed higher tear production levels than GB on the Schirmer's Tear Test on the first month of analysis, after which the levels observed between the two experimental groups remained similar (Figure 1C).

No significant difference was observed at the different time points within groups or between groups for episcleral congestion, blepharospasm, conjuctival hyperemia, epiphora, chemosis or ocular discharge. Nevertheless, epiphora was present in $16.67 \%$ of GB (1/6) and in $60 \%$ of GO $(3 / 5)$ throughout the period of analysis. One animal from the GB group was presented with severe inflammatory reaction characterized by conjuctival hyperemia, chemosis, episcleral congestion and severe mucous discharge on the first day after the occlusion of the lacrimal punctum. Another animal from the same group developed severe pruritus two days after occlusion. One animal from the GO group was presented with an inflammatory reaction 120 days after occlusion with conjuctival hyperemia, chemosis, blepharitis, severe episcleral congestion and mucous/serosanguineous discharge. Two animal from the same group developed sneezing during the first 5 days following occlusion.

No animal showed a positive result for the Jones test carried out on Day 70, however, on Day 180 one animal in each group was tested positive for the same test.

\section{DISCUSSION}

The technique for occlusion of the inferior lacrimal punctum and canaliculi used in this study proved to be safe and executable. The leakage of the adhesives into the conjuctival sac did not prove to be a problem as, once polymerized, it could be easily removed.

In a similar study, ROSA et al. (2012) opted to use ethyl cyanoacrylate in gel form to occlude the superior lacrimal canaliculi, as the rapid polymerization of this adhesive when in liquid form resulted in it becoming stuck to the cannula and, consequently, being pulled out of the canaliculi when the needle was removed (hypodermic needle). The use of a $24 \mathrm{G}$ catheter in this study, however; proved to be simple, safe and quick to use as it did not require adaptors such as those reported in the study by ROSA et al. (2012) with the use of hypodermic needles.

The Schirmer's Tear test is the most commonly used method to quantify tear production (BERGE \& KING, 1998; WILLIAMS, 2005; GELATT et al., 2006; GELATT, 2007). Commercial strips are available at the standard size of $35 \mathrm{~mm}$ thus, in this study; this represented the maximum value recorded, even though in some cases it may not have represented the actual volume of tear accumulated in the conjuctival sac of the eyes subjected to occlusion. The use of strips longer than the standard would have probably revealed different levels to those observed. WILLIAMS (2005) observed the process of tear absorption by the filter paper during the Schirmer's Tear test and reported that at the beginning the strip is rapidly filled by the tear present in the conjuctival sac but that the speed of absorption diminishes as the tear runs out and another freshly produced tear is deposited in the sac. Thus, by using the standard Schirmer's Tear test the time recorded for the filling of the strip could have been different if longer strips were used. 
(A)

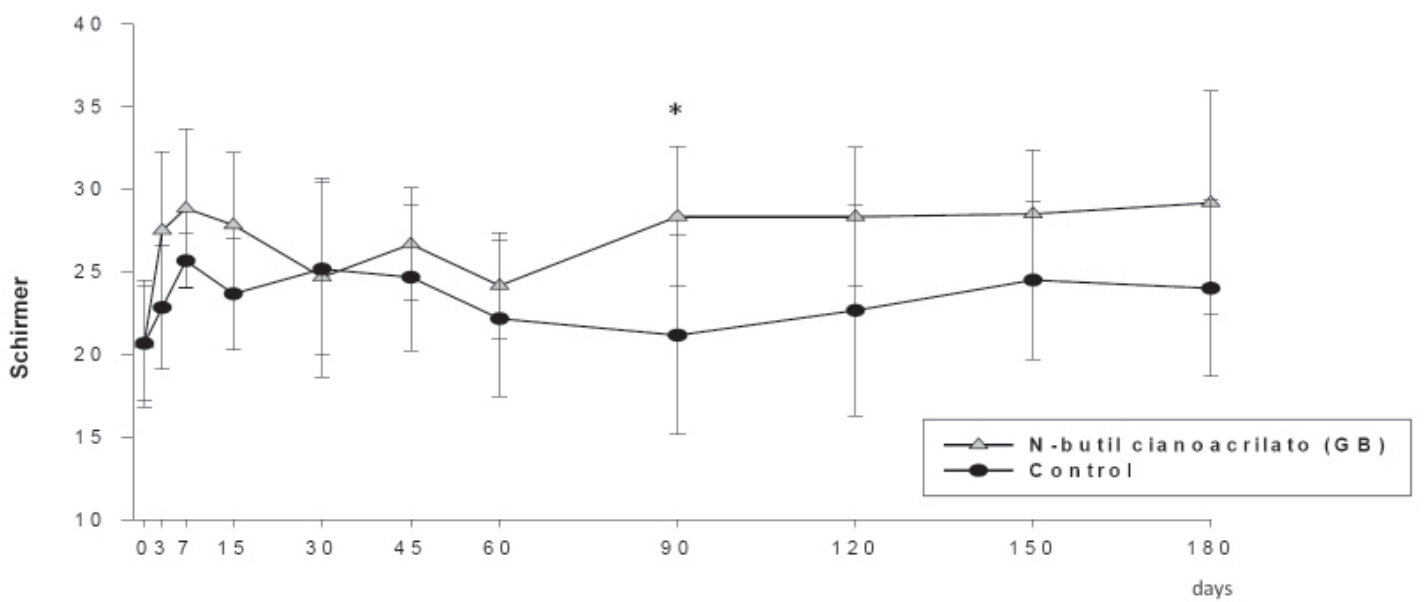

(B)
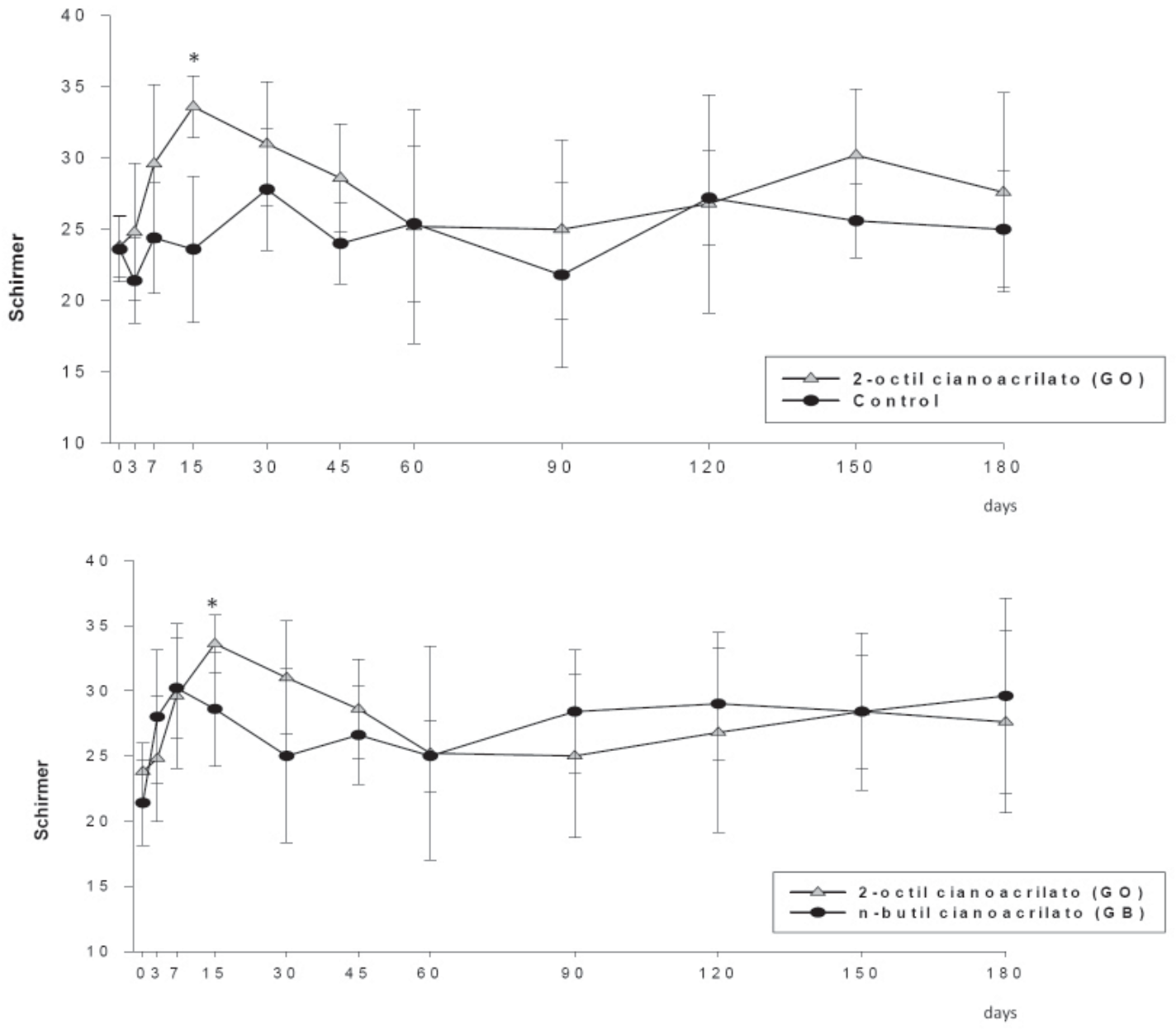

Figure 1 - Schirmer's Tear test (mmmin-1) values obtained at different times (days) in dogs subjected to occlusion of the inferior lacrimal punctum and canaliculi of the right eye. (A) Values obtained for treated (GB) and non-treated (control) animals in the n-butyl-cyanoacrylate group. (B) Values obtained for treated (GO) and non-treated (control) animals in the 2-octylcyanoacrylate group. (C) Comparison between the treated eyes of GB and GO. *Significance considered at $\mathrm{P} \leq 0.05$. 
Although the canine population used in this study was not homogeneous in relation to gender, age and body weight it is believed that these factors did not interfere with the obtained results as BERGER \& KING (1998) and de HARTLEY et al. (2006) previously reported that the use of mixed populations does not result in significant individual difference.

The increase in tear production by the control eye in the treatment groups is in agreement with the findings of WHITWELL (1961), which reported that the continuous stimulation of tear production in one eye resulted in similar increases in production by the contralateral eye. The accumulation of tears in the treated eye could have influenced the untreated contralateral eye (control) to produce greater quantity of tears by a reflex mechanism triggered by the central nervous system.

In the GB group, a continuous increase on the values from the Schrimer's Tear test could be observed up to day 7 . This increase could be related to the inflammatory response to the n-butylcyanoacrylate, as supported by CARDOSO et al. (2013). These authors used n-butyl-cyanoacrylate in the lacrimal canaliculi of rabbits and observed local diffuse inflammatory response on days 7 and 14 after occlusion. Similar results have been reported by MARCOVICH et al. (2001) on the histological analysis of the urinary tract of pigs after 7 days of n-butyl-acrylate being used.

The inflammatory response observed in this study may have induced serous production similar to that of the tear or the presence of the adhesive in the lacrimal canaliculi stimulated the tearing reflex and, consequently, influenced the Schrimer's Test results observed. On the other hand, the decline observed on days 30 and 60 and could be associated to the reduction of the inflammatory response. An increase in the Schrimer's test results could be observed at day 90 , which was kept stable until the end of analysis. This increase could have been related to the inflammatory response, as suggested by DIAMOND et al. (1995), which observed that when the same adhesive was used in the lacrimal canaliculi of humans there was a need for medical intervention in $12.5 \%$ of the eyes after 2 months of evaluation due to the severe inflammatory response associated with ocular discomfort in patients.

In the GO group, an increase in the Schirmer's Tear test results was observed on Day 15 after the occlusion due to the accumulation of tears in the conjuctival sac caused by drainage obstruction, as previously reported by PATEL \& GRIERSON (1994) when collagen implants were used as drainage occlusion methods in dogs.
When comparing both treated groups, GO initially showed Schirmer's Tear test values superior to those of GB. Although there was no significant difference between the two groups, greater conjuctival hyperemia was observed in the GO group soon after the procedure. These higher values could be the result of a tearing reflex triggered by local irritation to the adhesive (HERRING et al., 2000). Epiphora can represent anatomical defects or functional abnormalities that interfere with the tear drainage system (GELATT, 2007) and its occurrence could have been related to the greater inflammation response caused by the 2-octyl-cyanoacrylate, stimulating the tearing reflex (HERRING et al., 2000). The severity of the clinical signs of one animal from the GB group after 1 day of occlusion were similar to those previously reported by OLLIVIER et al. (2001) when using the same adhesive in the cornea of rabbits. These authors reported that histological evaluation showed elevated inflammatory response 4 and 6 days after n-butyl-cyanoacrylate application. Furthermore, CARDOSO et al. (2013) observed that in lacrimal canaliculi of rabbits occluded with the same adhesive there was local acute and diffuse inflammatory response which was greater than that observed for 2-octyl-cyanoacrylate. One animal from the GO group was presented with similar clinical signs after 120 days of the procedure, which could be characterized as a natural expelling reaction of the adhesive used.

The intense pruritus observed in an animal from the GB group one day after occlusion could have been associated to hypersensitivity to the adhesive (KOHLER, 1986). GAGNAIRE et al. (2003) studied the irritating potential of 2-ethyl-cyanoacrylate, 2-methyl-cyanoacrylate, 2-isopropyl-cyanoacrylate and 2-metoxiethyl-2-cyanoacrylate based on the strong irritating odor as well as the lacrimogenic effect of the cyanoacrylates during polymerization. These authors concluded that all of the above were potentially irritating to the nasal mucosa even in low concentrations, due to the release of isocyanates, alilic components, nitrogen trichloride, acrolein and paracetic acid. Thus, it could be suggested that besides the presence of the adhesive in the canaliculi, the release of these toxic substances may have contributed to the irritability potential to sensitive individuals resulting in greater tearing. Furthermore, the degradation that takes place after polymerization releases substances such as cyanoacetate and formaldehyde, which can also cause inflammation (MARCOVICH et al., 2001; GAGNAIRE et al., 2003; EL-DARS et al., 2010). 
The limiting factors for the use of 2-octyl-cyanoacrylate when compared to n-butylcyanoacrylate are cost and greater difficulty of acquisition. At the time of this study, 2-octylcyanoacrylate cost 10 times more than n-butylcyanoacrylate and both, in comparison to ethylcyanoacrylate used by ROSA et al. (2012), are expensive. However, both adhesives have longer carbon chains than ethyl-cyanoacrylate ensuring greater flexibility, resistance, adherence and degradation time and are (MARCOVICH et al., 2001), thus, more advantageous than ethylcyanoacrylate. On the other hand, when compared to silicone plugs, their cost and the time remained in situ could be considered as advantages. After 6 months of evaluation, only one animal in each group was tested positive for Jones' test, suggesting loss of obstruction. These results are still highly superior to the time of occlusion observed by GELATT et al. (2006) when using silicone plugs.

\section{CONCLUSION}

After 180 days of evaluation of dogs that had their lacrimal punctum and canaliculi occluded with n-butyl-cyanoacrylate and 2-octyl-cyanoacrylate, it was concluded that both adhesives provided good drainage occlusion for a long period of time and that the technique employed was easy to perform, making it a possible therapeutic option for dogs with lacrimal deficiency unresponsive to clinical treatment alone.

\section{ACKOWLEDGEMENTS}

The authors would like to thank the Coordenação de Aperfeiçoamento de Pessoal de Nível Superior (CAPES) for their support alongside the Programa de Suporte à Pós-Graduação de Instituições de Ensino Particulares (PROSUP).

\section{ETHICS COMMITTEE AND BIOSECURITY}

Protocol number 013/10.

\section{SOURCES OF ACQUISITION}

a - Vetbond ${ }^{\circledR}$ - 3M do Brasil, SP, Brasil;

b - Dermabond ${ }^{\circledR}$ - Johnson \& Johnson do Brasil Ind. Com. Prod. Saúde Ltda., SP, Brasil;

c - Acepran 0,2\% ${ }^{\circledR}$ - Vetnil Ind. Com. Prod. Vet. Ltda., SP, Brasil; d - Dolantina ${ }^{\circledR}$ - Sanofi Aventis Farmacêutica Ltda., SP, Brasil

e - Propovan ${ }^{\circledR}$ - Cristália Produtos Químicos Farmacêuticos Ltda., SP, Brasil;

$\mathrm{f}$ - Fentanest $\mathrm{F}^{\mathbb{}}$ - Cristália Produtos Químicos Farmacêuticos Ltda., SP, Brasil;

g - Teste Lacrimal de Schirmer - Ophthalmos Ind., SP, Brasil;

h - SigmaStat $3.5^{\circledR}$ - Systat Software Inc., CA, USA;

i - Fluoresceína strips - Ophthalmos Ind., SP, Brasil.

\section{REFERENCES}

ARVO. Statement for the use of animals in ophthalmic and visual research. Available from: <http://www.arvo.org/ About_ARVO/Policies/Statement_for_the_Use_of_Animals_in_ Ophthalmic_and_Visual_Research/>. Accessed: Abr. 30, 2013.

BERGER, S.L.; KING, V.L. The fluctuation of tear production in the dog. J Am Anim Hosp Assoc, v.34, n.1, p.79-83, 1998. Available from: $<$ http://www.ncbi.nlm.nih.gov/pubmed/9527434>. Acessed: Out. 17, 2013.

CARDOSO, K.C.F. et al. Clinical and histological effects of the temporary occlusion of the rabbit nasolacrimal duct and point using cyanoacrylate adhesives. Arq Bras Med Vet Zootec, v.65, n.6, p.1729-1737, 2013. Available from: <http://www.scielo.br/scielo. php?script=sci arttext\&pid=S0102-09352013000600021\&lng=en $\&$ nrm $=$ iso $>$. Accessed: Jan.11, 2014.

DIAMOND, J.P. et al.Cannalicular occlusion with cyanoacrylate adhesive: a new treatment for the dry eye. Eye, v.9, p.126-129, 1995. Available from: <http://dx.doi.org/10.1038/eye.1995.21>. Accessed: Out. 18, 2013. doi: 10.1038/eye.1995.21.

El-DARS, L.D. et al. Allergic contact dermatitis to Dermabond ${ }^{\circledR}$ after orthopaedic joint replacement. Contact Dermatitis, v.62, n.5, p.315-317, 2010. Available from: <http://dx.doi.org/10.11 11/j.1600-0536.2010.01720.x>. Accessed: Out. 18, 2013. doi: 10.1111/j.1600-0536.2010.01720.x.

GAGNAIRE, F. et al. Sensory irritation due to methyl-2cyanoacrylate, ethyl-2-cyanoacrylate, isopropyl-2-cyanoacrylate and 2-methoxyethyl-2-cyanoacrylate in mice. Ann Occup Hyg, v.47, n.4, p.297-304, 2003. Available from: <http://dx.doi. org/10.1093/annhyg/meg038>. Accessed: Out. 18, 2013. doi: 10.1093/annhyg/meg038.

GELATT, K.N. et al. Effect of lacrimal punctal occlusion on tear production and tear fluorescein dilution in normal dogs. Vet Ophthalmol, v.9, n.1, p.23-27, 2006. Available from: <http:// dx.doi.org/10.1111/j.1463-5224.2005.00430.x>. Accessed: Out. 18, 2013. doi: 10.1111/j.1463-5224.2005.00430.x.

GELATT, K. N. Veterinary ophthalmology. 4.ed. Oxford: Blackwell, 2007. 1672p.

HARTLEY, C. et al. Effect of age, gender, weight, and time of day on tear production in normal dogs. Vet Ophthalmol, v.9, n.1, p.53-57, 2006. Available from: <http://dx.doi.org/10.111 1/j.1463-5224.2005.00437.x>. Accessed: Out. 18, 2013. doi: 10.1111/j.1463-5224.2005.00437.x.

HERRING, I.P. et al. Evaluation of aqueous tear production in dogs following general anesthesia. J Am Anim Hosp Assoc, v.36, n.5, p.427-430, 2000. Available from: <www.ncbi.nlm.nih.gov/ pubmed/10997519|>. Accessed: Out. 18, 2013.

KAIDO, M. et al.Punctal occlusion in the management of chronic Stevens-Johnson Syndrome. Ophthalmology, v.111, n.5, p.895-900, 2004. Available from: <http://dx.doi.org/10.1016/j. ophtha.2003.09.034>. Accessed: Out. 18, 2013. doi: 10.1016/j. ophtha.2003.09.034.

KOHLER, chvorübergehendemTränennasenwegsverschlussmit Gewebekleber (Histoacryl ${ }^{\mathbb{}}$ ). Klin Mbl Augenheilk, v.189, p.486-490, 1986. Available from: <http://dx.doi. 
org/10.1055/s-2008-1050859>. Accessed: Out. 18, 2013. doi: $10.1055 / \mathrm{s}-2008-1050859$.

LIU, D.; SADHAN, Y. Surgical puctal occlusion: a prospective study. Brit J Ophthalmol, v.86, p.1031-1034, 2002. Available from: <http://bjo.bmj.com/content/86/9/1031.short>. Accessed: Out. 18, 2013. doi:10.1136/bjo.86.9.1031.

MAGGS, D.J. et al. Slatter's fundamentals of veterinary ophthalmology.5ed. St. Louis: Elsevier, 2013. 506p.

MARCOVICH, R. et al. Comparison of 2-octyl cyanoacrylate adhesive, fibrin glue, and suturing for wound closure in the porcine urinary tract. Urinary, v.4, p.806-810, 2001. Available from: $<$ http://dx.doi.org/10.1016/S0090-4295(00)01075-X>. Accessed: Out. 18, 2013. doi: 10.1016/S0090-4295(00)01075-X.

MURUBE, J.; MURUBE, E. Treatment of dry eye by blocking the lacrimal canaliculi. Surv Ophthalmol, v.40, n.6, p.46380, 1996. Available from: <http://dx.doi.org/10.1016/S00396257(96)82013-3>. Accessed: Out. 18, 2013.doi: 10.1016/S00396257(96)82013-3.

OHBA, E. et al. Surgical punctal occlusion with a high heat-energy releasing cautery device for severe dry eye with recurrent punctal plug extrusion. Am J Ophthalmol, v.151, n.3, p.483-487, 2011 Available from: <http://dx.doi.org/10.1016/j.ajo.2010.08.045>. Accessed:Out. 18, 2013.doi: 10.1016/j.ajo.2010.08.045.

OLLIVIER, F. et al. Tolerance of the rabbit cornea to an n-butylester cyanoacrylate adhesive $\left(\right.$ Vetbond $\left.^{\circledR}\right)$. Vet Ophthalmol, v.4 n.4, p.261-266, 2001. Available from: <http://dx.doi.org/10.10 46/j.1463-5216.2001.00195.x>. Accessed: Out. 18, 2013. doi: 10.1046/j.1463-5216.2001.00195.x.

PATEL, S.; GRIERSON, D. Effect of collagen punctal occlusion on tear stability and volume. Adv Exp Med Biol, v.350, p.605-
608, 1994. Available from: <http://dx.doi.org/10.1007/978-14615-2417-5 102>. Accessed: Out. 18, 2013. doi: 10.1007/978-14615-2417-5_102.

PATTEN, J.T. Punctal occlusion with n-butyl cyanoarcylate tissue adhesive. Ophthalmic Surg, v.7, p.24-26, 1976. Available from: <www.ncbi.nlm.nih.gov/pubmed/945531’. Accessed: Out. 17, 2013.

ROSA, A.S. et al. Obstrução do duto nasolacrimal com etilcianoacrilato como adjuvante no tratamento da ceratoconjuntivite seca em cães. Rev Bras Med Vet, v.34, n.4, p.353-360, 2012. Available from: <http://www.rbmv.com.br/pdf_artigos/21-122012_10-41RBMV\%20017.pdf>. Accessed: Out. 18, 2013.

SANCHEZ, R.F. et al. Canine keratoconjunctivitis sicca: disease trends in a review of 229 cases. J Small Anim Pract, v.48, p.211-217, 2007. Available from: <http://dx.doi.org/10.1 111/j.1748-5827.2006.00185.x>. Accessed: Out. 18, 2013. doi: 10.1111/j.1748-5827.2006.00185.x

WHITWELL, J. Role of the sympathetic in lacrimal secretion. Brit J Ophthalmol, v.45, p.439-445, 1961. Available from: <http:// dx.doi.org/10.1136/bjo.45.6.439>. Accessed: Out. 18, 2013. doi: 10.1136/bjo.45.6.439.

WILLIAMS, D.L. Analysis of tear uptake by the Schirmer tear test strip in the canine eye. Vet Ophthalmol, v.8, n.5, p.325-330, 2005. Available from: <http://onlinelibrary.wiley.com/doi/10.1111/ j.1463-5224.2005.00421.x/pdf $>$. Accessed: Out. 18, 2013. doi: 10.1111/j.1463-5224.2005.00421.x.

YEN, M.T. et al. The effect of punctal occlusion on tear production, tear clearance, and ocular surface sensation in normal subjects. Am J Ophthalmol, v.131, n.3, p.314-323, 2001. Available from: <http://dx.doi.org/10.1016/S0002-9394(00)00822-9>. Accessed: Out. 18, 2013. doi: 10.1016/S0002-9394(00)00822-9. 